\title{
Intimate Enemies: Representations of Perpetrators in Literary Responses to the 1994 Genocide in Rwanda
}

\author{
Nicki Hitchcott
}

Between April and July 1994, as many as one million Rwandan people were brutally killed. ${ }^{1}$ One of the distinguishing features of the Genocide against the Tutsi was the mass participation of ordinary citizens in the killings. ${ }^{2}$ Victims were often attacked by neighbours, friends and even members of their own families. It is difficult, if not to say impossible to know exactly how many people actually took part in acts of genocide in 1994. Estimated numbers range from tens of thousands to as many as 3 million people slaughtering between 800,000 and 1 million victims. ${ }^{3}$ Indeed, the extraordinarily high number of civilians involved, directly or indirectly, in acts of torture, mutilation, killing and rape, often accompanied by looting and damage to property was, as an African Rights report reminds us, 'unprecedented in the world'. 4 Describing her visit to an overcrowded Rwandan prison in 1998, Ivorian author Véronique Tadjo writes that ' $[\mathrm{t}]$ he whole of society is represented here: former politicians, businessmen, civil servants, managers, teachers, artists, schoolchildren, students, peasant farmers, doctors, women, priests, pastors, nuns'. ${ }^{5}$

\footnotetext{
${ }^{1}$ What follows is closely based on a chapter in my book, Rwanda Genocide Stories: Fiction After 1994 (Liverpool: Liverpool University Press, 2015), pp. 160-89. I am grateful to Liverpool University Press for permission to reprint.

${ }^{2}$ The official name for the genocide in Rwanda acknowledges that the majority of victims were Tutsi. While most of the perpetrators were Hutu, some Hutu who resisted the genocide or were associated with Tutsi were also killed. Both 'Hutu' and 'Tutsi' were designated by colonial powers as ethnic groups based on perceived physiological differences. However, research has shown that any differences were in fact differences of class rather than ethnicity. Both groups share the same language, the same religion and the same customs (René Lemarchand, The Dynamics of Violence in Central Africa (Philadelphia, PA: University of Pennsylvania Press, 2009), pp. 49-50).

${ }^{3}$ Scott Straus, 'How Many Perpetrators were there in the Rwandan Genocide? An Estimate', Journal of Genocide Research, 6 (2004), 85-98 (85). Based on his own empirical research, Straus estimates that between 175,000 and 210,000 Rwandan people committed acts of genocide between April and July 1994 (93). ${ }^{4}$ African Rights and Redress, Survivors and Justice in Post-Genocide Rwanda: their Experiences, Perspectives and Hopes (London: African Rights, 2008), p. 6.

${ }^{5}$ Véronique Tadjo, The Shadow of Imana: Travels in the Heart of Rwanda, trans. by Véronique Wakerley (Oxford: Heinemann, 2002), p. 98. Where no published translation exists, translations are my own.
} 
Authors of fiction portray killers across the full range of those who participated, including Rwandan professionals such as burgomasters, priests, teachers and doctors, as well as those that Lee Anne Fujii calls 'Joiners', that is 'the lowestlevel participants in the genocide [who] were responsible for committing much of the violence directed at Tutsi in their communities'. ${ }^{6}$ As Scott Straus has shown, the majority of the killers were male: they were 'average adult Hutu men - in terms of age, education, paternity, and occupation' ${ }^{7}$ Although women did participate in many different ways in the genocide, often as leaders, organisers, looters or informants, and sometimes as killers, the majority of Rwandan génocidaires were men. ${ }^{8}$ Reflecting the reality of what happened in 1994, most fictional perpetrators are also male, but some authors, notably Tadjo, do reflect on female perpetrators, as I explore later in this chapter. Through a discussion of the ways in which those who participated in acts of extreme violence in Rwanda are represented in fictional texts, I will consider how authors and readers often find themselves in a position of moral ambivalence in relation to these imagined perpetrators of genocide. Questions of empathy and judgement are often evoked, pushing readers to reconsider their own moral categories and ultimately to ask themselves what they would have done.

In 'His voice', one of the short fictional pieces that forms part of her complex travel narrative, The Shadow of Imana (2002), Tadjo tells the story of Isaro, whose husband Romain hanged himself when he was accused of having murdered a woman and her three children in the genocide. ${ }^{9}$ Some years later, Isaro receives a phone call from a man who speaks with the voice of her dead husband. Excited to hear again the voice of the man she loved, Isaro arranges to meet the stranger, hoping that her husband's spirit has returned from the dead. The stranger turns out to be Nkuranya, the same man whose wife and children were allegedly killed by Romain. In creating a fictional survivor with the voice of a dead perpetrator, Tadjo confounds the distinction between victim and perpetrator, fusing them together in a single character. At the same time, she emphasises the very intimate nature of the 1994 genocide and its

\footnotetext{
${ }^{6}$ Lee Anne Fujii, Killing Neighbors: Webs of Violence in Rwanda (Ithaca, NY: Cornell UP, 2011), p. 129.

${ }^{7}$ Scott Straus, The Order of Genocide: Race, Power, and War in Rwanda (Ithaca: Cornell University Press, 2006), p. 108.

${ }^{8}$ Ibid., pp. 100-01.

${ }^{9}$ Tadjo, The Shadow of Imana was originally published in French as L'Ombre d'Imana: voyages au bout du Rwanda (Arles: Actes Sud, 2000).
} 
afterlife: as friends became enemies during the one hundred days of horror, so enemies have become friends in post-genocide Rwanda.

As this example from Tadjo's text suggests, the lines between perpetrator and victim are not always clearly drawn in fictional responses to 1994. Yet, not all fictional Rwandan perpetrators are morally ambiguous. On the contrary, some writers use fiction as means of exposing and unequivocally condemning the actions of those who were in positions of responsibility in Rwandan communities, particularly priests. It is not without significance that two of the earliest francophone novels by Rwandans both explicitly criticise the role of the Catholic Church in the genocide. ${ }^{10}$ Both Camille Karangwa and Benjamin Sehene create fictionalised versions of perpetrator priests. In the case of Le Feu sous la soutane [Fire Beneath the Cassock, 2005], Sehene's narrator, Father Stanislas, is clearly based on infamous real-life priest Wenceslas Munyeshyaka of the Eglise Sainte Famille in Kigali who, charged with multiple counts of genocide, including rape, continues to live and work with impunity in France. ${ }^{11}$ In Le Chapelet et la machette [The Rosary and the Machete, 2003], Karangwa's central protagonist, Célestin Gahinda is a headteacher and activist in the MNRD [Mouvement Révolutionnaire National pour le Développement], the party that planned and orchestrated the genocide. Behind Célestin is the shadowy figure of Father Dominique, a Belgian missionary and former supporter of the Hutu extremist movement, Parmehutu. ${ }^{12}$ Like Wenceslas/Stanislas, Father Dominique collaborates with the génocidaires to deliver Tutsi to their death before fleeing to France for his personal safety. The choice of fiction to expose the immoral actions of the purveyors of Christian morality is an ambiguous one, since the credibility of the story risks being undermined. This no doubt explains both authors' insistence on the resemblance to real-life perpetrators. Just as Karangwa links his novel to reality with the opposite of a disclaimer when he explains that this novel is based on prototypes of real people,

\footnotetext{
${ }^{10}$ For a history of Rwandan literary cultural production, see my book, Rwanda Genocide Stories, pp. 29-54.

${ }^{11}$ Benjamin Sehene, Le Feu sous la soutane: un prêtre au coeur du génocide rwandais (Paris: L'Esprit frappeur, 2005). For more detailed discussion of this novel, see Nicki Hitchcott, 'Wenceslas Benjamin Sehene vs. Father Wenceslas Munyeshyaka: The Fictional Trial of a Genocide Priest', Journal of African Cultural Studies, 24.1 (2012), 21-34.

${ }^{12}$ Camille Karangwa, Le Chapelet et la machette: sur les traces du genocide rwandais (Pretoria: Editions du jour, 2003).
} 
so the back cover blurb of Le Feu sous la soutane states explicitly that Sehene's novel is inspired by a true story.

Although exceptional examples such as genocide priests make for powerful works of fiction, many perpetrators in Rwanda genocide stories are not political leaders or priests, but everyday men who are often relatives or friends of their victims. Many authors draw perpetrators as quite unremarkable individuals, reflecting what James Waller emphasises as the 'ordinariness' of those who commit acts of 'extraordinary human evil'. ${ }^{13}$ This ordinariness is brilliantly illustrated in Robert Lyons and Scott Straus's 2006 study, Intimate Enemy, in which interviews by Straus with convicted male Rwandan perpetrators are followed by a series of photographs by Lyons of a different set of prisoners, including some women. Writing about the interview process in the introduction to the book, Straus remarks that,

Very soon it became clear that these killers were men who had led quite banal lives before the genocide. They were ordinary husbands, fathers, sons, and boyfriends; they were farmers, fishermen, teachers, and market salesmen. Even more disarming, their testimonies made a certain sense; their rationales were not those of demented, sadistic maniacs. They were narratives of men with a well-developed sense of self-protection. This, of course, is the disturbing conclusion that other scholars who study genocide perpetrators have reached: the aggregate crime is much more extraordinary than those who commit it. ${ }^{14}$

Unlike the photographs in the better-known collection, Les Blessures du silence [Wounds of Silence, 2001] by Rwandan survivor, Yolande Mukagasana and Belgian photographer, Alain Kazinierakis, ${ }^{15}$ Lyons's photographs have no captions. Instead, an index of the plates is placed at the end of the book in which thumbnail photographs are reproduced alongside short biographical summaries of the subjects including details of any crime they have allegedly committed. Among the photographs of

\footnotetext{
${ }^{13}$ James E. Waller, Becoming Evil: How Ordinary People Commit Genocide and Mass Killing, second edition (Oxford: Oxford University Press, 2007), p. 9.

${ }^{14}$ Robert Lyons and Scott Straus, Intimate Enemy: Images and Voices of the Rwandan Genocide (New York: Zone Books, 2006), p. 24.

${ }^{15}$ Yolande Mukagasana and Alain Kazinierakis, Les Blessures du silence: témoignages du génocide au Rwanda (Arles: Actes Sud, 2001).
} 
prisoners, Lyons intersperses a small number of pictures of survivors, also without captions, making it impossible to distinguish the innocent from the guilty without referring to the index of plates, thereby emphasising the ordinariness and randomness of those who committed the most extraordinary acts of genocide. Lyons confirms this as his aim in the 'Photographer's Notes' that precede the pictures, explaining that he 'wanted to make the audience enter a more intimate space, ask questions, experience directly the ambiguous physical resemblances between génocidaire and survivor' ${ }^{16}$ As in Les Blessures du silence, readers of Intimate Enemy are confronted with neutral, close-up portraits of ordinary men and women that challenge the clichéd images of machete-wielding militiamen drunk and high on cannabis that have become associated with Rwanda. In their place, we find what the photographer suggests is 'a more human face' of genocide. ${ }^{17}$

Many Rwandan perpetrators were known to their victims; some of them members of their own families. They were, as Straus and Lyons stress, 'intimate' killers. This intimacy is particularly striking in Rwandan author, Jean-Marie Rurangwa's novel, Au sortir de l'enfer [Exiting Hell, 2006], where Hutu extremist and ruthless killer Casimir Kayiru is the uncle of the protagonist's wife. Thinking her uncle will protect them when the killings begin, Jeanne-Laurette is horrified to hear Casimir tell her he has cut off her father's head and genitals as punishment for marrying a Tutsi. ${ }^{18}$ Although on one level, emotional closeness makes acts of genocide even more difficult to understand; on another, it perhaps explains the preoccupation with attempting to understand perpetrators in works of fiction. Whereas Charlotte Lacoste rejects fictional attempts to understand génocidaires as reactionary, revisionist and ultimately undermining victims' stories, ${ }^{19}$ attempts to present the humanity of perpetrators are found in different degrees in novels by authors with a range of different positional relationships with the events of 1994. Lacoste notes with disapproval the sympathetic representation of perpetrator Dr Joseph Karekezi in Senegalese author, Boubacar Boris Diop's novel Murambi, The Book of Bones (2006). ${ }^{20}$ Although a cold-blooded, resolute killer, Karekezi is portrayed as someone

\footnotetext{
${ }^{16}$ Lyons and Straus, Intimate Enemy, p. 32.

${ }^{17}$ Ibid., p. 35.

${ }^{18}$ Jean-Marie V. Rurangwa, Au sortir de l'enfer (Paris: L'Harmattan, 2006), p. 78.

${ }^{19}$ Charlotte Lacoste, Séductions du bourreau (Paris: PUF, 2010).

${ }^{20}$ First published in French as Murambi, le livre des ossements (Abidjan: Nouvelles Editions Africaines, 2000).
} 
who was once an idealistic man of principle. ${ }^{21} \mathrm{~A}$ liberal Hutu, he was married to a Tutsi woman and formerly tortured in prison for being a Tutsi sympathiser. Yet, after the genocide, he justifies having ordered the death of his own wife and two of their children with no sign of remorse. 'It's just history that wants blood', he explains. 'And why would I only spill other people's? Theirs is just as rotten'. ${ }^{22}$

In his novel, Diop describes how Karekezi intrigues other characters who were witnesses to the genocide. French army officer, Colonel Etienne Perrin describes his reaction to this architect of mass killing as 'the sort of repugnance and fascination one feels in the presence of sadistic murderers they talk about in the newspaper' ${ }^{23}$ Survivor Siméon wonders if his brother-in-law, Karekezi was actually insane. How else, he asks himself, could he have done what he did? By presenting secondary characters interrogating the actions of Karekezi in the novel, Diop highlights what the text underlines as the urge to understand how people commit genocide. Ultimately, Siméon can only explain Karekezi's actions as driven by power and greed. As Noémie Bénard suggests, Diop uses Murambi to outline the limits of understanding genocide since what ultimately emerges is the incomprehensibility and senselessness of it all. ${ }^{24}$ Yet, attempts at understanding are what link many of the fictional responses to the genocide in Rwanda.

While a small number of fictional texts, notably Rurangwa's Au sortir de l'enfer and US author, Julian Pierce's Speak Rwanda (1999), portray génocidaires as single-minded and ruthless perpetrators of evil, ${ }^{25}$ the majority of the novels convey killers as far more complex individuals. Some men are depicted as vulnerable, sometimes afraid, unquestioningly following orders for fear of their own death; others like Robusto Kana's Rwandan army brigadier in Le Défi de survivre [The Challenge to Survive, 2009], show symptoms of post-traumatic stress disorder ${ }^{26}$; in particular, many confound the distinction between victim and perpetrator, a blurring that is

\footnotetext{
${ }^{21}$ Ibid., pp. 252-53.

${ }^{22}$ Boubacar Boris Diop, Murambi, the Book of Bones, trans. by Fiona Mc Laughlin (Bloomington: Indiana Univeristy Press, 2006), p. 107.

${ }^{23}$ Ibid., p. 116.

${ }^{24}$ Noémie Bénard, 'Le "témoignage" sur le génocide rwandais en littérature d'Afrique noire francophone: Tierno Monénembo et Boubacar Boris Diop', Lendemains, 112 (2003, special issue Rwanda - 2004: témoignages et littérature), 82-91 (88).

${ }^{25}$ Julian R. Pierce, Speak Rwanda (New York: Picador, 1999).

${ }^{26}$ Robusto Kana, Le Défi de survivre (Aix-en-Provence: Persée, 2009).
} 
brilliantly illustrated in Robert Lyons's photographs. ${ }^{27}$ What is particularly striking in fiction is the fact that some of the most fully drawn examples of génocidaires appear in three of the earliest francophone Rwandan texts: Karangwa's portrait of a head teacher turned genocide leader in Le Chapelet et la machette, Sehene's fictionalised confession of real-life alleged perpetrator-priest Wenceslas Munyeshyaka in Le Feu sous la soutane, and Gilbert Gatore's mute militiaman, Niko in The Past Ahead (2012). ${ }^{28}$ In each of these cases, the relationship of the author to the events of 1994 is markedly different: a survivor now living in South Africa (Karangwa), an exiled RPF (Rwandan Patriotric Front) sympathiser who was living in France in 1994 (Sehene), and the son of an alleged perpetrator who fled Rwanda with his family during the genocide (Gatore). Yet, all have chosen to create what Froma Zeitlin writing about the Holocaust calls 'imaginary tales in the land of the perpetrators' ${ }^{29}$ Unlike Holocaust literature, however, these three texts were published only ten or so years after the genocide.

According to Robert Eaglestone, what unites all perpetrator fictions about the Holocaust is the desire for an answer to the question of why such atrocities were committed. ${ }^{30}$ Where dominant motives emerge in genocide fiction about Rwanda, these tend to be presented as personal rather than structural. Although all the novels critique the historical processes that contributed to the genocide, individual perpetrators are imagined as most commonly driven by motives of greed, peer pressure and fear. Sexual revenge against Tutsi women is the suggested motive of two of the more extreme examples of gendered violence performed by CDR (Coalition pour la Défense de la République) militants Célestin Sembagare and Casimir Kayiru in Rurangwa's Au sortir de l'enfer. In his portrayal of Célestin, Rurangwa presents a character who joins the génocidaires out of a desire for revenge for being spurned by Tutsi women in the past. Rurangwa describes Célestin waiting anxiously in

\footnotetext{
${ }^{27}$ There many are other brief portraits of perpetrators as remorseless killers in genocide fiction, for example the character of Alfred Ndimabati in Monique Ilboudo, Murekatete (Bamako and Lille: Le Figuier/Fest'Africa, 2000). See Josias Semujanga, Le Génocide, sujet de fiction? (Montreal: Nota Bene, 2008), pp. 188-91.

${ }^{28}$ Gilbert Gatore, The Past Ahead, trans. by Marjolijn de Jager (Bloomington: Indiana University Press, 2012), originally published in French as Le Passé devant soi (Paris: Phébus, 2008).

${ }^{29}$ Froma Zeitlin, 'Imaginary Tales in the Land of the Perpetrators', Journal of Modern Jewish Studies, 5.2 (2006), 213-28.

${ }^{30}$ Robert Eaglestone, 'Avoiding Evil in Perpetrator Fiction', Holocaust Studies: A Journal of Culture and History, 17.2-3 (2011), 13-26 (15-16).
} 
anticipation for the genocide to begin so that he can 'commit those erotic atrocities and give free rein to his most monstrous sexual fantasies', including gang rape and sexual violence. ${ }^{31}$ Through Célestin's words, Rurangwa evokes the myth perpetuated by Hutu extremists that Tutsi women thought they were too good for Hutu men and so rape was a morally justifiable act of revenge. When fellow CDR militant, Casimir rapes his brother's wife he tells her, 'I'm going to fuck you, Tutsi bitch! I've fancied you for so long!'.32 Alison Des Forges explains that, '[g]enerally esteemed as beautiful, Tutsi women were also said to scorn Hutu men whom they found unworthy of their attention. Many assailants insulted women for their supposed arrogance while they were raping them'. ${ }^{33}$ In Le Feu sous la soutane, Sehene's perpetrator-priest Stanislas also attempts to justify his rape of the women in his care when he tells himself, 'I must never forget the arrogance and disdain that Tutsi women have for us. Didn't they use to say before the conflict, "the ugly goat - the Hutu - can never ride the sheep"'. ${ }^{34}$ Such projected ethnic hatred can be traced back to the resentment towards the Tutsi monarchy that preceded the so-called Rwandan social revolution of $1959^{35}$ and reflects what Lemarchard refers to as the 'disproportionate part' played by Tutsi women in extremist Hutu propaganda and genocide ideology. ${ }^{36}$

However, among the ordinary killers in fiction, the "joiners" motives tend not to be framed in terms of the ideology of genocide, a narrative choice that fits the

\footnotetext{
31 'commettre ces atrocities érotiques et donner libre cours à ses fantasmes sexuels les plus monstrueux'. Rurangwa, Au sortir de l'enfer, p. 71.

32 'Je vais te baiser, chienne de Tutsi! Comme je t'ai longtemps convoitée!'. Ibid., p. 81. The possibility of raping Tutsi women was one of the ways in which the CDR attempted to persuade Rwandan citizens to participate in the genocide (Jennie E. Burnet, Genocide Lives in Us: Women, Memory and Silence in Rwanda (Madison, WI: University of Wisconsin Press, 2012), p. 62). Rurangwa illustrates this in $A u$ Sortir de l'enfer through the conversation between CDR militant Butihoro and the Benimana family's domestic servant, Juma. Rurangwa, Au sortir de l'enfer, pp. 1617.

${ }^{33}$ Alison Des Forges, 'Leave None to Tell the Story': Genocide in Rwanda (New York: Human Rights Watch, 1999), p. 215.

34 'il ne faut jamais que j'oublie l'arrogance et le mépris des femmes tutsi pour nous. Ne disaient-elles pas avant le conflit: "Le vilain bouc - le Hutu - ne peut monter la brebis"". Sehene, Le Feu sous la soutane, p. 115.

${ }^{35}$ The 'Social Revolution' of 1959 involved mass killing of Tutsi and the rise to power of Parmehutu (the Hutu emancipation party). Supported by the Belgians, the so-called revolution paved the way for an overwhelming victory for Parmehutu party in the first municipal elections in 1960 and later in the first parliamentary elections, following independence, in 1961.

${ }^{36}$ Lemarchand, The Dynamics of Violence in Central Africa, pp. 60-63.
} 
evidence from scholars' fieldwork in Rwanda. Often the most violent perpetrators were, like Rurangwa's militants, indoctrinated by anti-Tutsi propaganda. Yet, the majority of those who perpetrated, as Straus's research shows, did not support Hutu Power or its ideology, at least before the genocide. ${ }^{37}$ Of 210 convicted male perpetrators interviewed by Straus in 2002, 64 per cent claimed to have participated in killings because of the threat of repercussions if they failed to do so. Threatened repercussions included damage to property, financial penalties, violence and death. ${ }^{38}$ When Tadjo visited Rwanda, she also interviewed perpetrators. Similar findings to those gathered by scholars like Straus appear to have informed the characterisation in The Shadow of Imana. For example, perpetrator Isaac explains how the militia took young people and forced them to fight and kill, warning that, 'If you do not kill, we will kill you. If you do not kill them, they will kill you!'. ${ }^{39}$ Diop's novel, Murambi on the other hand, is more critical of those who joined the Interahamwe militia, described by survivor Siméon as greedy, stupid, fearful of the authorities and bowing to ingroup pressure. ${ }^{40}$ Intra-ethnic coercion was a significant factor driving people to participate in the genocide in 1994 and was, according to Straus, a more important determinant of participation than interethnic animosity. ${ }^{41}$

Ultimately, as Straus points out, 'any search for a single motivation that causes individuals to commit genocide is surely a futile exercise. Motivation and participation were clearly heterogeneous in the Rwandan genocide, and Rwanda is not exceptional in that regard'. ${ }^{42}$ Just as existing fieldwork among prisoners in Rwanda fails to reach a consensus on why people perpetrated genocide, so the motives of perpetrators in Rwandan novels are not always easy to identify, with writers tending to focus on how rather than why the genocide happened. ${ }^{43}$ On the other hand, many fictional works do attempt to portray génocidaires with a degree of psychological complexity that resists reducing perpetrators to an identifiable type. For example, in

\footnotetext{
${ }^{37}$ Straus, The Order of Genocide, pp. 129-35.

${ }^{38}$ Ibid., p. 136.

${ }^{39}$ Tadjo, The Shadow of Imana, p. 22.

${ }^{40}$ Diop, Murambi, p. 184.

${ }^{41}$ Strauss, The Order of Genocide, p. 148. Testimony gathered by Fujii also reveals that genocide leaders used social ties to coerce family members, sometimes with the threat of death, into participating in the killings. Fujii, Killing Neighbors, pp. 134-37. ${ }^{42}$ Straus, The Order of Genocide, p. 95.

${ }^{43}$ Anneleen Spiessens, 'La Mise en scène du bourreau: Jean Hatzfeld et Gilbert Gatore', Témoigner: entre histoire et mémoire, 102 (2009), 29-39 (30).
} 
Le Défi de survivre, Kana portrays a Rwandan army brigadier who is suffering from post-traumatic impotence. As an army leader who ordered crimes of genocide, the brigadier is a Category I perpetrator according to Rwandan law. Yet, the novel presents him as emasculated by his experience, unable to make love to his wife because "the multiple scenes of horror in which he had been an unwitting participant or a witness had left too much bitterness in his body'. ${ }^{4}$

Moral ambiguity surrounds the representation of the majority of perpetrators in Rwanda genocide fiction. A striking feature of many of the texts, particularly those by Rwandan authors, is the blurring of the categories of perpetrator and victim demonstrated in the Lyons and Straus photography project discussed above. The strongest fictional example of this is found in Gatore's novel, The Past Ahead, which won the French fiction prize Prix des Etonnants Voyageurs in 2008 and has been something of a commercial success. ${ }^{45}$ In this novel, Gatore creates a symmetrical narrative, which alternates between a female survivor's and a male perpetrator's points of view. Both are presented as traumatised individuals, struggling to recover from their experiences of genocide, the survivor, Isaro, attempting first to repress then to work through her trauma, the former militiaman, Niko, living in isolation in a cave where he experiences nightmares, flashbacks and other post-traumatic symptoms. During his initiation into the militia, Niko is given three seconds to murder his own father. Counting down from three to one, a militiaman stands behind Niko with a gun against his head. Niko chooses a club as a weapon so he won't see any blood.

Gatore's description of the killing, as Elizabeth Applegate remarks, 'complicates our judgement' of Niko, identifying him as perpetrator but also suggesting that he too was a victim and perhaps even a survivor. ${ }^{46}$ If anything, the reader is invited to empathise more closely with perpetrator than with survivor, particularly as, in the original French, the narrator directly addresses the reader as 'tu' in Niko's narrative compared with the more formal 'vous' in Isaro's story, as Spiessens reminds us. ${ }^{47}$ Although Gatore's attempt to paint a fictional portrait of a génocidaire's subjectivity is by no

\footnotetext{
44 'les multiples scènes d'horreur dont il avait été acteur involontaire ou témoin avaient laissé trop d'amertume dans son corps'. Kana, Le Défi de survivre, p. 149. ${ }^{45}$ Gatore, The Past Ahead.

${ }^{46}$ Elizabeth Applegate, 'Reimagining the Swallow and the Toad: Narrating Identity and Reconciliation in Postgenocide Rwanda', Research in African Literatures, 43.1 (2012), 71-87 (72).

${ }^{47}$ Spiessens, 'La Mise en scène du bourreau', 36.
} 
means unique, it has unleashed something of a scandal in the academic world. Critic, Catherine Coquio has openly dismissed The Past Ahead as a failed genocide novel because it encourages the reader to empathise with a killer, an empathy that she claims is neither possible nor true. ${ }^{48}$ Lacoste takes an even more condemnatory view, accusing Gatore of literary revisionism. ${ }^{49}$

Yet, the concept of perpetrators as victims is not so easy to reject in the context of the genocide in Rwanda. Writing about her testimonial photography project, Les Blessures du silence, Rwandan survivor, Mukagasana criticises the tendency to condemn all perpetrators en masse. What she discovered in Rwanda in 1999, she writes, was that 'among the perpetrators, there are a certain number who are victims of having been perpetrators' ${ }^{50}$ Indeed, the testimonies of a number of the perpetrators included in Mukagasana's book challenge conventional notions of innocence and guilt. For example, she includes the case of Hutu mother and prisoner, Ancilla M., who killed three of her four Tutsi children by forcing them to drink insecticide. Ancilla did this, she says, because she was not able to hide them any more. ${ }^{51}$ Ancilla then attempted to take her own life, but failed because there was not enough insecticide left. She tells Mukagasana that she longs for a death sentence and has so many regrets that she is unable to sleep at night. Mukagasana writes in response that she feels pity for Ancilla and that 'her wound is immense and will bleed until the end of her days'. ${ }^{2}$

The question of whether perpetrators can be victims has been a contentious subject in the field of trauma theory, with Ruth Leys famously challenging Cathy Caruth's claim that perpetrators can be understood as victims of trauma. ${ }^{53} \mathrm{In}$ Multidirectional Memory, Michael Rothberg engages with the Leys versus Caruth

${ }^{48}$ Catherine Coquio, 'Poétiser l'enfant tueur. Questions sur Le passé devant soi de G. Gatore', in 'J'ai tué'. Violence guerrière et fiction, ed. by Déborah Lévy-Bertherat and Pierre Schoentjes (Geneva: Droz, 2010), pp. 231-65 (p. 258).

${ }^{49}$ Lacoste, Séductions du bourreau, pp. 347-48.

50 'parmi les bourreaux, il y en a un certain nombre qui sont victimes d'être bourreaux'. Mukagasana and Kazinierakis, Les Blessures du silence, p. 82.

${ }^{51}$ Ancilla M. is also one of the perpetrators photographed in Lyons and Straus, named here as 'confessed Category II génocidaire, Ancille Mukaminega'. Lyons and Straus, Intimate Enemy, p. 151; p. 175.

52 'sa blessure est immense et saignera jusqu'à la fin de ses jours'. Mukagasana and Kazinierakis, Les Blessures du silence, p. 109.

${ }^{53}$ Ruth Leys, Trauma: A Genealogy (Chicago: University of Chicago Press, 2000), p. 297. 
debate, suggesting that 'Leys's and other critics' observations derive in part from a category error. Most crucially, Leys elides the category of "victim" with that of the traumatized subject'. ${ }^{54}$ Like Caruth, Rothberg acknowledges that perpetrators can be victims of trauma because, he explains, 'the categories of victim and perpetrator derive from either a legal or a moral discourse, but the concept of trauma emerges from a diagnostic realm that lies beyond guilt and innocence or good and evil'. ${ }^{55}$ However, acknowledging the possibility of a traumatised perpetrator does not, in Rothberg's view, allow us to conceive of a perpetrator as a victim. Rothberg writes that 'perpetrators of extreme violence can suffer from trauma - but this makes them no less guilty of their crimes and does not entail claims to victimization or even demands on our sympathy'. ${ }^{56}$ What Rothberg's attempt to simplify the distinction between traumatised individual and victim does not do, however, is consider the subject position of a perpetrator forced into performing acts of violence, as happened often in Rwanda. In cases such as these, I would argue that the concept of victim also lies beyond guilt and innocence or good and evil; the distinctions are no longer entirely clear. Although Rothberg's argument seems to exclude all possibility of a sympathetic perpetrator, a view that resonates with Coquio's rejection of Gatore's novel, this is challenged by Rwandan survivors like Mukagasana who seek to understand - and even empathise with - those who committed acts of genocide. ${ }^{57}$

Another interviewee in Les Blessures du silence is 15 year-old Evariste, who was ten at the time of the genocide. When the militia came to his house, they told Evariste that they would kill his Tutsi mother if he did not take a machete to his neighbor's children. Reflecting on Evariste's story, Mukagasana writes, 'Evariste made me look at myself as a mother. If I had married a Hutu, then perhaps my children would have been perpetrators!'. ${ }^{58}$ All of Mukagasana's own children were

\footnotetext{
${ }^{54}$ Michael Rothberg, Multidirectional Memory: Remembering the Holocaust in the Age of Decolonization (Stanford: Stanford University Press, 2009), p. 90.

55 Ibid.

${ }^{56}$ Ibid.

${ }^{57}$ Rothberg later seems to contradict himself when, concluding his discussion of the story of Tancred and Clorinda as a multidirectional narrative, he posits that Tasso's parable 'stages the permeable relation, in cultural texts as well as history, between enemies "inside" and "outside" of empire as well as between "perpetrators" and "victims" and "enemies" and "friends". Ibid., p. 95.

58 'Evariste m'a mise en face de moi-même en tant que mère. Si j'avais épousé un Hutu, mes enfants auraient peut-être été des bourreaux!'. Mukagasana and Kazinierakis, Les Blessures du silence, p. 97.
} 
massacred in the genocide; yet, she is able to imagine herself as the mother of a perpetrator. Through her emotional responses to Ancilla and Evariste, Mukagasana demonstrates precisely the empathic identification that Coquio finds so unacceptable in Gatore's novel.

Of course, imagining the humanity of perpetrators who have committed acts of such unimaginable horror is a risky business because it requires empathy, an emotional response that makes both author and reader ethically and aesthetically uncomfortable. Empathising with a perpetrator runs the risks of mitigating their crimes and negating the experiences of victims, not to mention the fear that readers will somehow be contaminated by the perpetrator's ideology although, in the case of Rwanda, there is evidence to suggest that most ordinary perpetrators did not in fact subscribe to the 'genocide ideology'. 59

Some authors use their texts to position perpetrators in terms of a moral hierarchy. For example, in The Shadow of Imana, Tadjo's portrait of 253 women prisoners suggests that she is personally more shocked by the acts of female perpetrators than those by male perpetrators: 'We would have preferred them [the women] to be innocent', she writes. ${ }^{60}$ As evidence of what appears to be her moral outrage, Tadjo catalogues crimes committed by women in what reads as a long, relentless list. ${ }^{61}$ Here the frequent repetition of the word 'women' draws particular attention to the gender of the perpetrators, as do the references to the women prisoners as mothers, culminating in the use of a metaphor of childbirth in the final sentence in this section: 'Only impunity gives birth to death' ${ }^{62}$ Tadjo's apparent difficultly in reconciling women's 'roles' with perpetrating genocide is echoed in the findings of Sarah Brown who records the Executive Secretary of Ibuka (the umbrella organisation for Rwandan survivors), Janvier Forongo, telling her in 2011 that 'it's somehow very difficult for us to understand how a lady can become a killer, as a mother'. ${ }^{63}$ Brown goes on to explain that, '[f]ar from being a cliché, gendered assumptions about the

\footnotetext{
${ }^{59}$ Anuradha Chakravarty, 'Navigating the Middle Ground: the Political Values of Ordinary Hutu in Post-Genocide Rwanda', African Affairs, 113.451 (2014), 232-53 (233).

${ }^{60}$ Tadjo, The Shadow of Imana, p. 102.

${ }^{61}$ None of the crimes Tadjo lists was specific to women whereas women were often the targets of particular gender-based acts of violence.

${ }^{62}$ Tadjo, The Shadow of Imana, p. 102.

${ }^{63}$ Sarah E. Brown, 'Female Perpetrators of the Rwandan Genocide', International Journal of Feminist Politics, 16.3 (2014), 448-69 (449).
} 
sacredness of motherhood and female passivity are still real in their function and application in Rwandan society, despite the country's tremendous success in the are of gender equality'. ${ }^{64}$ Tadjo seems to share the view that women perpetrators of genocide, particularly mothers, are somehow more 'unnatural' than men. She writes that, 'these women killed their own destiny as women'. ${ }^{65}$ Such authorial interventions leave the reader in an uncomfortable position, one that Eaglestone has also identified in Holocaust perpetrator novels where ethical and aesthetic discomfort 'are often made manifest as questions of moral judgement: the judgements readers make on texts, but more often judgements that texts contain within themselves or lead the reader to make', 66

Some novelists also present characters who make judgements on themselves. These tend to be relatives of perpetrators or bystanders who feel contaminated by their close contact with acts of genocide. The two most powerful examples of characters who experience guilt by association are Théodore Gakwavu in Rurangwa's Au sortir de l'enfer and Cornelius, the main protagonist in Diop's Murambi. While in Belgium, Rurangwa's protagonist Jean-Léonard encounters Rwandan former university professor Théodore Gakwavu who is described by his friend André-Martin as 'off his head'. ${ }^{67}$ Although Théodore himself refused to participate in the genocide, he witnessed his brother Théodomir lead a group of Interahamwe in killing his colleague, Philibert Semunuma, along with Philibert's three children and his wife who was also gang-raped and lacerated through her vagina. A broken man, Théodore is described as 'morally loaded with his brother's crime" ${ }^{68}$ and is haunted by the image of the dead colleague decapitated by his brother. To demonstrate the extent of his trauma, Rurangwa gives Théodore a ten-page psychotic monologue addressed to the ghost of Philibert. During this monologue Théodore assumes responsibility for crimes he did not commit, claiming he took a machete, cut off Philibert's head and then threw it into a latrine. Théodore believes that if he tells a story of the genocide, even if it is not true, he will be free of the ghost of Philibert, symbol of his personal guilt and trauma.

\footnotetext{
64 Ibid., 451.

${ }^{65}$ Tadjo, The Shadow of Imana, p. 102.

${ }^{66}$ Eaglestone, 'Avoiding Evil in Perpetrator Fiction', 15.

67 'détraqué'. Rurangwa, Au sortir de l'enfer, p. 135.

68 'port[ant] moralement le crime commis par son frère'. Ibid., p. 136.
} 
In Murambi, Cornelius also experiences guilt by association, an emotion that is intensified by his visit to the Murambi memorial. Having discovered that his father, Dr Joseph Karekezi, organised the massacre of 50,000 people in the unfinished buildings of what was to be the Murambi technical school, Cornelius wants to tell the guide that he himself was personally responsible for what happened there, but as he acknowledges, that would not make any sense at all. What such examples show is the complex nature of guilt and blame in post-genocide Rwanda. As Mahmood Mamdani points out, "from the point of view of the minority in postgenocide Rwanda, the majority is guilty, either of killing, or condoning, or just looking elsewhere while the killing happened'. ${ }^{69}$ What writers of fiction also suggest is that the majority of Rwandans are also victims, including many of those who perpetrated genocide. The difficulty of pushing people into categories of victim or perpetrator is powerfully illustrated in Diop's novel when Cornelius, having initially positioned himself and his family as victims in the shared memory of genocide, is forced to re-evaluate his position once he discovers the truth about his father's role in the killings. Diop writes that, 'from that day on his life would not be the same. He was the son of a monster. [...] He had suddenly discovered that he had become the perfect Rwandan: both guilty and a victim' ${ }^{70}$

As Diop suggests here, guilt in Rwanda is not limited to those who perpetrated genocide, nor is it always easy to distinguish the innocent from the guilty. However, in post-genocide Rwanda, as Nigel Eltringham demonstrates, there is a tendency to 'globalize guilt according to ethnic identity'. ${ }^{71}$ Writers of fiction offer more nuanced perspectives and deconstruct the association of Hutu with perpetrator. For example, in Le Défi de survivre, Kana creates the character of Simon, a Hutu with a Tutsi mother, who hides two of his Tutsi neighbors in his house and takes another away for medical treatment concealed in the back of his van. Despite saving three lives, Simon is all too aware that he will be judged by his Hutu 'ethnicity'. As he tells his father when the genocide is over, 'Unfortunately, even innocent people will have to share that

\footnotetext{
${ }^{69}$ Mahmood Mamdani, When Victims Become Killers: Colonialism, Nativism, and the Genocide in Rwanda (Princeton: Princeton University Press, 2001), p. 225.

${ }^{70}$ Diop, Murambi, p. 78.

${ }^{71}$ Nigel Eltringham, Accounting for Horror: Post-Genocide Debates in Rwanda (London: Pluto Press, 2004), p. 69.
} 
shame' ${ }^{72}$ His neighbour and RPF soldier Michel Tabaro is initially reluctant to visit Simon after the genocide because Simon is Hutu. Although he knows that Simon's houseboy took his sister Gisèle to safety, Michel cannot be sure of his neighbour's innocence. Despite the pro-RPF partisanship of his novel, Kana is careful not to condemn all Hutu as collectively guilty. Through the character of Simon, Kana challenges the way in which Hutu has become a synonym for perpetrator and Tutsi for victim in the national and international consciousness. Furthermore, Le Défi de survivre reminds us that a number of Tutsi also participated in the genocide, some of them organising and leading the killing. Simon talks to his wife about the president of the Interahamwe militia who was also a Tutsi. Here the text is referring to real-life génocidaire, Robert Kajuga, founder and president of the Interahamwe. Both Kajuga's parents were Tutsi but he and his family 'passed' as Hutu. ${ }^{73}$

Like Kana from Rwanda, Guinean author Tierno Monénembo uses fiction to challenge the ethnopolitics that have become so strongly associated with Rwanda and the genocide. In The Oldest Orphan, Faustin has a Hutu father and Tutsi mother, so would be identified as a Hutu by the genocidal regime. When he asks his father whether he is Hutu or Tutsi, his father explains: 'Hutu, Tutsi, that doesn't mean much; you might as well compare water with water' ${ }^{74}$ Throughout his novel, Monénembo demonstrates the arbitrary nature of so-called ethnic identity in Rwanda. When he is taken prisoner by an RPF soldier, Faustin is assumed to be a génocidaire, however the soldier also informs him that he could be mistaken for a Tutsi. Monénembo is careful not to reveal the truth about Faustin's experience until the very end of the novel when a flashback finds him nursing at his dead mother's breasts, which are dripping with blood after the massacre at Nyamata church. By keeping the reader guessing about both Faustin's ethnicity and his role in the genocide, Monénembo demonstrates what he sees as the absurdity of the genocide and its afterlife. As Faustin wryly comments, 'since these famous advents, everything works upside down'. ${ }^{75}$ Monénembo's

\footnotetext{
72 'Malheureusement, même les innocents auront à partager cette honte'. Kana, Le Défi de survivre, p. 212.

${ }^{73}$ Kajuga's brother Wyclif was one of the Tutsi hidden at the Mille Collines hotel during the genocide. Paul R. Bartrop, A Biographical Encyclopedia of Contemporary Genocide: Portraits of Evil and Good (Santa Barbara: ABC-CLIO, 2012), pp. 15354.

74 Tierno Monénembo, The Oldest Orphan, trans. by Monique Fleury Nagem (Lincoln, NE: University of Nebraska Press, 2004), p. 85.

${ }^{75}$ Ibid., p. 55.
} 
Rwanda is a topsy-turvy world in which identity and truth are relative and arbitrary. For much of the novel, he manipulates the reader into identifying Faustin as a perpetrator, particularly as the novel opens with him in Kigali's central prison awaiting execution. When she visits him in prison, Claudine, Faustin's benefactor, speaks to him about his possible sentence as if he were being tried for a crime of genocide:

'The judge told me there are three categories of guilty individuals: the accomplices (zero to five years), those who carry out the deed (five to twenty years) and the organizers (life or the gallows). However, you're a special case. You've always been a special case, Faustin Nsenghimana! ${ }^{76}$

Faustin does not fit any of the categories listed by the judge because these are the categories for crimes of genocide. His crime is to have shot dead another orphan he found having sex with his sister. Despite not being a génocidaire, Faustin is sentenced to death, however the text suggests that is largely because he behaves disrespectfully in court and shows no remorse for what he has done. Throughout the novel, Monénembo leads the reader into placing Faustin into different categories at different times: Hutu, Tutsi, perpetrator, victim. When the story of what really happened to Faustin is finally revealed, the reader is invited to identify him as a survivor. Yet, as a Rwandan Hutu, Faustin would not officially be considered a survivor of genocide, despite being a traumatised orphan who experienced one of the most well-known and brutal massacres, and who witnessed many murders, including the murder of real-life genocide heroine, Antonia Locatelli, and the brutal slaughter of both his own parents. $^{77}$

Through Faustin's story, Monénembo draws attention to the inadequacies of the criminal justice system in Rwanda. Faustin's death sentence seems disproportionate and arbitrary, particularly when read against the context of the genocide. ${ }^{78}$ The difficulties of achieving justice that is proportionate and fair are also articulated in Tadjo's text when a prisoner complains that there was no death penalty

\footnotetext{
${ }^{76}$ Ibid., p. 52.

${ }^{77}$ Antonia Locatelli was an Italian nun who was killed outside Nyamata church while trying to help Tutsi flee the violence.

${ }^{78}$ The death penalty was officially abolished in Rwanda for all crimes in 2007.
} 
at the International Criminal Tribunal for Rwanda in Arusha, Tanzania, where the masterminds of the genocide faced trial: 'It's only the little folk who are executed' ${ }^{79}$ The Oldest Orphan portrays a country in which justice, like every other aspect of society, has been turned upside down since 1994 and nothing makes any sense anymore. Outraged by Faustin's insolence and vulgarity, the judge condemns this traumatised orphan as an inhuman monster using terms more often associated with perpetrators of genocide. In the judge's final words, 'Get this [vermin] out of here before I lose control', ${ }^{80}$ the use of the word 'vermin' creates a chilling echo of the génocidaires' condemnation of the Tutsi as cockroaches that had to be eliminated, further undermining the suitability of legal processes in Rwanda.

'Genocide overwhelms justice', James Waller observes. ${ }^{81}$ No criminal justice system has ever been designed to deal with the prosecution of genocide, but justice is essential if Rwanda is to move successfully towards peace and reconciliation.

Although a report into post-genocide justice reveals widespread dissatisfaction with systems of justice in Rwanda, it nevertheless emphasises survivors' need for 'some measure of justice that is meaningful to them' even though survivors understand and accept that 'justice could only ever be a partial response to the crimes' ${ }^{82}$ The importance of justice for survivors and their families is implied in works of fiction through frequent examples of individuals' inabilities to find answers to questions about what happened in the genocide. For Rwandan writers, this no doubt reflects their personal frustration at finding themselves often unable to find out about lost family members and to bring those responsible for their death to trial.

As survivors and perpetrators find themselves having to live together as neighbors in Rwanda after 1994, there is a pressing need for mutual understanding. Perpetrators' stories are an essential part of the quest for justice for survivors, but are also necessary for reconciliation and future genocide prevention. This need for

\footnotetext{
${ }^{79}$ Tadjo, The Shadow of Imana, p. 100. Earlier in the novel, Tadjo recalls the public executions at Nyamirambo (not Nyamata) stadium where, on 24 April 1998, a total of 24 people including Froduald were killed by firing squad (p. 36) See https://trialinternational.org/latest-post/froduald-karamira/ [accessed 24 October 2016].

${ }^{80}$ Monénembo, The Oldest Orphan, p. 84. I have altered the published translation here, as Monique Fleury Nagen's translation of 'vermine' as 'scum' loses the association with cockroaches.

${ }^{81}$ Waller, Becoming Evil, p. 16.

${ }^{82}$ African Rights and Redress, Survivors and Justice in Post-Genocide Rwanda, p. 4.
} 
understanding is reflected in the testimonial photography projects of Lyons and Straus, and Mukagasana and Kazinierakis, but also in creative writers' attempts to explain the actions of perpetrators through works of the imagination. What fiction can do is explore the complexities of the multiple failures of humanity that culminated in genocide. Through their texts, authors such as Tadjo, Karangwa, Sehene and Gatore challenge the familiar but reductive readings of the genocide as: tribal conflict, African barbarity or absolute evil, offering instead nuanced reflections on the ordinary people who participated in such extraordinary horror. Moreover, by creating texts in which readers can sympathise, or even empathise, with perpetrators of genocide, writers of fiction also invite us to question ourselves. What, Tadjo asks, would she have done in 1994? 'In the dark night of absolute blindness, what would I have done if I had been caught up in the spiraling violence of the massacre? Would I have resisted betrayal? Would I have been cowardly or brave? Would I have killed or would I have let myself be killed? Rwanda is inside me, in you, in all of us' ${ }^{83}$

Fiction provides an effective space for reflecting on these questions. In 'His Voice', Tadjo's protagonist never finds out whether her husband, Romain, was guilty or not, but the story ends with his alleged victim, Nkuranya telling her that Rwandan society needs to move on: 'We must punish those who deserve to be punished, those who began the reign of cruelty. But the others must be freed of the burden of guilt' ${ }^{84}$ At the end of Gatore's The Past Ahead, we discover that Niko the perpetrator is in fact a character in the book that Isaro, the survivor, is writing. When challenged about the character of Niko, Gatore explained that he asked himself the following question: 'what happens inside someone's head to transform him or her into a perpetrator?'. 85 As in Tadjo's story, Gatore imagines a survivor who speaks with the voice of a perpetrator, suggesting that the way towards peace and reconciliation is precisely through individuals putting themselves inside other people's heads and trying to understand what, on the face of it, is utterly incomprehensible.

\footnotetext{
${ }^{83}$ Tadjo, The Shadow of Imana, p. 37.

${ }^{84}$ Ibid., p. 57.

85 'qu'est-ce qui se passe dans la tête de quelqu'un pour le transformer en bourreau?'. 'Guerre et fiction: représenter la violence personnelle. Une rencontre avec F. Bernard, P. Chauvel, G. Gatore et L. Mauvignier, animée par Pierre Schoentjes', in 'J'ai tué', ed. by Lévy-Bertherat and Schoentjes, pp. 267-302 (p. 296).
} 